\title{
Beauty and the beast: Endoscopic resection of superficial esophageal cancer
}

\author{
Dean P. Schraufnagel, MD, Siva Raja, MD, PhD, and Alejandro C. Bribriesco, MD
}

\author{
From the Department of Thoracic and Cardiovascular surgery, Heart and Vascular Institute, Cleveland Clinic, \\ Cleveland, Ohio. \\ Disclosures: Authors have nothing to disclose with regard to commercial support. \\ Received for publication Oct 4, 2018; accepted for publication Oct 4, 2018. \\ Address for reprints: Siva Raja, MD, PhD, Cleveland Clinic Foundation, 9500 Euclid Ave J4-1, Cleveland, OH \\ 44195 (E-mail: rajas@ccf.org). \\ J Thorac Cardiovasc Surg 2019;157:403 \\ $0022-5223 / \$ 36.00$ \\ Copyright (C) 2018 Published by Elsevier Inc. on behalf of The American Association for Thoracic Surgery \\ https://doi.org/10.1016/j.jtcvs.2018.10.004
}

The beauty of endoscopic treatment of superficial esophageal cancer is obvious: accurate staging and potentially definitive treatment while avoiding the morbidity of an esophagectomy. Advancement in endoscopic techniques guided by interest in organ preservation has spurred increasingly aggressive resection of tumors deeper into the esophagus. ${ }^{1}$ The beast lurking below is the risk of leaving behind occult lymph node metastasis (LNM) and missing the opportunity to potentially cure the disease if an esophagectomy would have been performed instead. This conflict is at the heart of the therapeutic dilemma for superficial esophageal cancer. Once the decision has been made to perform endoscopic resection and the pathology is revealed, the nagging question remains: What is risk is the risk of LNM? Did beauty or beast prevail? present data on the risk of metastasis in superficial esophageal cancers along with a predictive tool to address this important issue. The group retrospectively reviewed patients who had undergone endoscopic resection or esophagectomy for superficial squamous cell cancer and performed a multivariate regression to assess which histologic findings were most associated with LNM. With this information, they created a simple score based on 3 factors: tumor size, depth of invasion, and lymphovascular invasion. By assigning points to each of these variables, low-risk and high-risk groups were defined with reasonable discrimination for predicting residual LNM after endoscopic resection. Of note, depth of invasion into the submucosa (T1b) was the strongest risk factor and assigned the highest score in the model. Ma and colleagues ${ }^{2}$ are to be commended for developing a tool that aids in identifying patients at high risk for noncurative endoscopic resection. The limitation of that study is that patients who underwent endoscopic therapy did not or could not have complete pathological staging that was accomplished in the resection group.

This findings of this article align with previous work that established the submucosa as a "watershed" area for
In this month's issue of the Journal, Ma and colleagues ${ }^{2}$

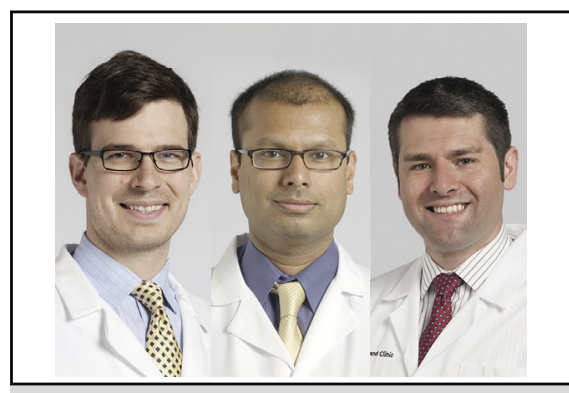

Dean P. Schraufnagel, MD, Siva Raja, MD, PhD, and Alejandro C. Bribriesco, MD

\section{Central Message}

Superficial esophageal cancer may not be early esophageal cancer. In the era of endoscopic therapy for superficial cancers, a scoring system to predict LNM is proposed.

See Article page 397.
LNM. $^{3}$ It adds new information about the relative risk of LNM due to tumor length and lymphovascular invasion in mucosal cancers. This invites the provocative question of what can be done when superficial [cancer] behaves like deep [cancer]? A recent multi-institutional study provided reassuring data demonstrating that patients found to have $\mathrm{T} 1 \mathrm{~b}$ involvement after endoscopic resection were able to successfully salvaged by subsequent esophagectomy. ${ }^{4}$ When coupled with Ma and colleagues' pathologic scoring system, ${ }^{2}$ the decision to offer endoscopic therapy or proceed to more radical therapy (ie, esophagectomy) becomes easier as the risk of LNM can be predicted. In other words, beauty is only mucosa deep, but the beast of LNM can and perhaps should still be tamed by esophagectomy.

\section{References}

1. Aadam AA, Abe S. Endoscopic submucosal dissection for superficial esophageal cancer. Dis Esophagus. 2018;31:7.

2. Ma DW, Jung DH, Kim J-H, Park JJ, Youn YH, Park H. Predicting lymph node metastasis for endoscopic resection of superficial esophageal squamous cell carcinoma. J Thorac Cardiovasc Surg. 2019;157:397-402.e1.

3. Raja S, Rice TW, Goldblum JR, Rybicki LA, Murthy SC, Mason DP, et al. Esoph ageal submucosa: the watershed for esophageal cancer. J Thorac Cardiovasc Surg. 2011;142:1403-11.e1401.

4. Molena D, Schlottmann F, Boys JA, Blackmon SH, Dickinson KJ, Dunst CM, et al Esophagectomy following endoscopic resection of submucosal esophageal cancer: a highly curative procedure even with nodal metastases. J Gastrointest Surg. 2017;21:62-7. 